\title{
A STUDY OF A LOW-COST EDIBLE-NEST SWIFTLET MASTER HOUSE
}

\author{
CHOKCHAI LUEANGTHUWAPRANIT*, NUTTAPONG BOVORNRUANGROJ AND \\ THAINTIP KRAIPROM
}

Department of Technology and Industries, Faculty of Science and Technology, Prince of Songkla University, Pattani 94000 , Thailand.

*Corresponding author: gchokchai@gmail.com

Submitted final draft: 22 June $2020 \quad$ Accepted: 14 August 2020

http://doi.org/10.46754/jssm.2021.06.009

\begin{abstract}
We present in this paper the construction of a low-cost edible-nest swiftlet master house, the settlement of swiftlets, nesting, nest production, costs and the payback period. Data was collected from April 2010 to April 2016. The master house was constructed as a single-story building, $5 \mathrm{~m}$ wide x $13.5 \mathrm{~m}$ long x $4 \mathrm{~m}$ high. Edible-nest swiftlets (Aerodramus fuciphaga), were attracted to live in the master house and build nests. The nests were attached to a plank and construction takes four to five weeks. The female bird of a pair usually lays a clutch of two eggs, which are brooded co-operatively by the pair. After hatching, the young swiftlets are reared by the parent until they are able to fly in five to six weeks. The average weight of the nests was $7.77 \pm 0.48 \mathrm{~g}$. The air temperature and relative humidity in the master house averaged $28.27 \pm 0.01^{\circ} \mathrm{C}$ and $82.56 \pm 0.03 \%$ respectively. The specific growth rate of the bird's nest population was $8.9 \%$ per month. The return on investment was calculated for average prices per kilogram of USD893 and USD596, for which the payback period was 3.3 and 5.7 years, respectively.
\end{abstract}

Keywords: Aerodramus fuciphaga, farming, breeding, behaviour, nesting.

\section{Introduction}

Edible-nest swiftlets are small swifts from the family Apodidae, subfamily Apodinae, genus Collocaliini (Chantler, 1999; David et al., 2016), inhabiting the Indo-Pacific region and reaching their greatest numbers in South-East Asia (Kang \& Lee, 1991; Chantler, 1995; Sankaran, 2001; David et al., 2016). The swiftlet constructs a nest with its saliva, which is harvested and exported to the Chinese market as a food delicacy and source of pharmaceutical products. Chinese people have been eating the nests for more than 1,500 years (Jandam, 2017; Hamza et al., 2018). It is believed that the nest has both nutritional and medicinal properties that help prevent or cure various diseases. Contemporary research found that proteins in the bird's nest have a bacteriostatic property which inhibits the growth of bacteria (Marcone, 2005). Bird's nest extract is also found to inhibit viral infections that cause the common cold and flu. Bird's nest also contains substances that inhibit the haemagglutination of viruses to red blood cells (Howe et al., 1960; 1961; Biddle \& Belyavin, 1968; Goh et al., 2001; Guo et al., 2006; Yagi et al., 2008). In addition, bird's nest extract can boost the activity of the epidermal growth factor, and hence the growth of skin cells, which slows down the aging of cells in the body, repairs bone mass, removes wrinkles of women in menopause and keeps the skin youthful (Kong et al., 1987; 1989; Matsukawa et al., 2011). Moreover, the glycoprotein in bird's nest is involved in the processes of fibroblast cells, connective tissue, and the brain and central nervous system (Nakagawa et al., 2007; Lee \& Kamini, 2009).

Recently, an abundance of buildings have been constructed to attract edible-nest swiftlets to live and nest. Because these birds present an economic opportunity, many houses for swiftlets have been built in the Pak Panang district of Nakhon Sri Thammarat province, Thailand, and other nearby provinces, such as Pattani, Yala and Narathiwat (Jandam, 2017). In addition to the southern provinces, swiftlet houses have also been built in the central, northern and north eastern parts of Thailand. The farming of bird's nest is growing rapidly, but it is not easy for most people to participate in the industry since the construction of an edible-nest swiftlet house requires high capital investment. Therefore, researchers at the Faculty of Science 
and Technology, Prince of Songkla University, Pattani Campus have studied and designed a low-cost edible-nest swiftlet master house and collected data between April, 2010, and up to the time of writing 2019. We investigate how the design of the master house affects the ediblenest swiftlets, especially with regard to their habitat, livelihood, breeding, nesting and egglaying. Furthermore, the temperature, humidity and lighting in the master house, as well as the the harvesting of the nests, the growth of the bird's nest population and the cost of and returns from the master house were also investigated. The knowledge gained from this study will be beneficial to the development of low-cost edible-nest swiftlet master houses, which can be constructed by farmers who wish to start a business.

\section{Materials and Methods}

\section{Construction of the Edible-Nest Swiftlet Master House}

The low-cost edible-nest swiftlet master house was designed by applying ideas gained from exploring the original swiftlet houses in Pattani province. The design emphasized low-cost and using locally available inexpensive traditional materials of good quality.. The house is a single-story roofed building, $5 \mathrm{~m}$ wide $\mathrm{x} 13.5 \mathrm{~m}$ long and $4 \mathrm{~m}$ high. The structure of the house includes steel bars and the walls are built from light-weight bricks. The roof is tiled with Roman tiles, and rises $2 \mathrm{~m}$ above the ceiling with the inside surface of the roof lined with aluminium foil and padded with 2 inches of insulation. Wooden grilles are fixed at both ends of the gables to ventilate the roof. There is a 60 $x 60 \mathrm{~cm}$ entrance hole in the front of the house. Under the roof, the ceiling is formed from 8 -inch wide and 1-inch thick hardwood planks for nesting, installed in sections of $60 \times 30 \mathrm{~cm}$, with a total area of 60 square meters. Holes are drilled into the house wall and lined with 6-inch PVC pipe for ventilation. On the floor, there is a faucet and a $60 \mathrm{~cm}$ wide trough parallel to the house wall on both sides. Electrical equipment, including a closed-circuit television system and speakers broadcasting swiftlets calls, is installed at the entrance hole, and there is also a humidifier in the house to maintain the correct humidity (Figure 1). The cost of construction, including materials and wages for the workers, was USD12,004. The edible-nest swiftlet master house was constructed in 2010 and continues operating in 2020.

\section{Methods and Sampling}

The study of how the master house affects the edible-nest swiftlets was conducted between April 2010 and April 2016. The number of bird's nests in the building was counted every 2 months, and the results were plotted against the age of the house. The specific growth rate of the bird's nest population was calculated during the exponential phase of growth, as described by Krebs (1972). The behavior and number of swiftlets inside or outside the house was investigated through CCTV footage, which could be replayed as required (Altmann, 1973). The birds' nesting, breeding and egg-laying behavior and growth of the bird population in the master house was in the house, and the lifespan of each pair of birds was recorded from the beginning of nesting. The length of the nesting time, the most appropriate time for nesting, and the position and size of the nests were observed. The size of the nests, the number of eggs laid in them, their colour, size and shape, the manner and timing of hatching, the behavior and growth of the nestlings, and how the bird's nests were harvested were also studied (Langham, 1980; Pongchu, 1985; Kang et al., 1991; Nguyen, 1994; Lim, 1999; Viruhpintu, 2002; Ratree, 2003). Additionally, data on the master house's air temperature, relative humidity and lighting were analyzed from detectors in the house, which automatically recorded the data hourly (Pongchu, 1985; Ponak, 2007; Ibrahim et al., 2009). Furthermore, the costs and returns from farming edible-nest swifts were studied according to the methods suggested by Brigham and Houston (2001) and Brigham and Ehrhardt (2004), and all the data were analyzed using the statistical methods suggested by Steel and Torrie (1980). 


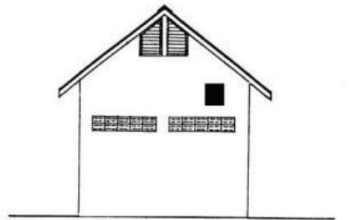

Front View $1: 100$

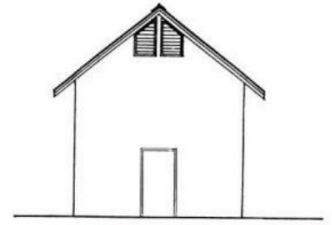

Rear View $1: 100$

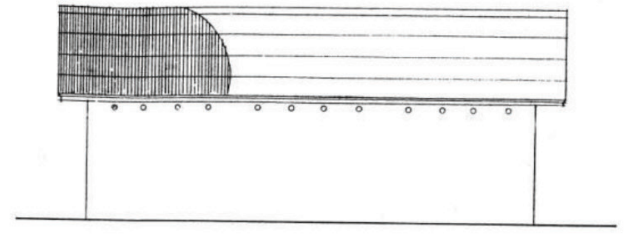

Right Side View $1: 100$

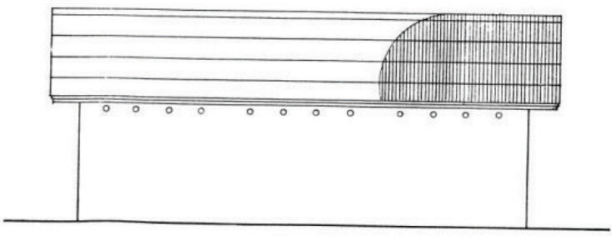

Left Side View $1: 100$

\section{Results and Discussion}

\section{Data relating to Swiftlets' Living in a Master House}

Based on CCTV observations in the first week, there were no birds living in the house even though bird calls were broadcast from the entrance hole. Some swiftlets were observed every day flying over the roof close to the speaker, especially in the early morning and late evening. In the following week some birds flew into the house to inspect it for a short time but then flew back out. This bird behavior occurred for some weeks and the birds took a long time inspecting the inside of the new house until they felt familiar with it. After a month, the data from the CCTV revealed that some birds flew into the house and did not fly back out and it could be assumed that the birds were nesting in the house. After 6 months, researchers went into the house and found that there were some bird droppings on the floor, especially near the humidifier, and there was also a bird's nest attached to the plank near the speaker and this was the first nest that was achieved by this project.

\section{Shape and Appearance of Edible-Nest Swiftlets}

The edible-nest swiftlets living in the master house are of the species Aerodramus fuciphaga and are also known as white-nest swiftlets.
They are about $12 \mathrm{~cm}$ long, and male and female birds are of a similar size with a short, broad triangular beak. The plumage and iris are black but they have a white or pale grey bar across their rump, contrasting with a dark back and tail. Their wings are long, covering the tail when folded into the body and are narrow, like a bow, when extended. The tail tip is rounded or slightly forked and they have short legs, the shins being covered with hair, and small feet with four toes, and the claws are long and curved, poking forward without any back toe (Langham, 1980; Pongchu, 1985; Lekagul \& Round, 1991; Chantler, 1995; Chantler, 1999; Lim, 1999; Viruhpintu, et al., 2002; Robson, 2008; David et al., 2016). Inside the master house, the birds perch by using their curved claws to grasp a plank on its perpendicular edge.

\section{Behaviour}

The swiftlets' behavior in the master house was observed from April 2010 to April 2016. It was observed that the birds fly in or out of the house the whole day. But most of them fly out in the early morning or when the sky brightens between $5 \mathrm{am}$ and $7 \mathrm{am}$ in search of food. They fly back in the evening, when the sky gets dark between $6.30 \mathrm{pm}$ and $8.30 \mathrm{pm}$. The edible-nest swiftlet is, therefore, classified as a diurnal bird, 
which seeks food during the day. In July and August, there will be numerous non-local birds flying over the house and visiting the entrance hole, with a lot of birds flying in and out of the house during the daytime (Figure 2).

The swiftlets could often be seen, especially in the late evening, flying over the house and the entrance hole uttering a "jok jak" sound, like a flock of sparrows. particularly heightened activity of leaving and returning to the house was observed during the mating and laying seasons and the subsequent period when the birds brood their eggs or feed their chicks in the nest. On a sunny day, the birds do not fly back until the evening. However, on cloudy or rainy days, they fly back earlier than normal and will fly around above the house, but on days of heavy rain, the birds will not go out until the rain has almost stopped.

The edible-nest swiftlet is a fast flying bird that can glide. It will flap several times and spread its wings to glide, and can maintain level flight or glide in a circle or in more complex patterns. While gliding, its wings appear slender like a bow. According to Viruhpintu (2002) and Hamza et al. (2018), the swiftlets have big eyes and very good eyesight. They can fly and use their beaks to catch insects (ie, diptera, homoptera, hymenoptera, coleoptera) in the air. They are likely to fly as a small flock above forests, mangrove forests and electrical lights at dusk or even above rivers where they are able to hover just above the surface of the water. During the day, birds flying outside the house utter a "jeep jeep" sound, but at night in the darkened house, the birds will make a "clik clik" sound as they emit high frequency sound waves in order to use echolocation to navigate around objects in flight and to locate their nests. According to Pongchu (1985) and Jandam (2017), swiftlets remember their nests well, and even if the nest is taken away, it will be rebuilt in the same place. The pairs of birds use their sharp curved claws to perch on a plank in the house together. If they have a nest, they will hold on to its edge, and if their nest contains eggs or chicks, one the birds will hatch or sit on them in the nest.

\section{Breeding Season, Nesting and Laying}

Swiftlets can reproduce all year round, although eggs are mostly laid in March, April and May. According to Pongchu (1985) and Jandam (2017), the edible-nest swiftlet can reproduce throughout the year, particularly in summer between January and April. The nest is made from the bird's saliva, and shaped like a half cup attached to the plank. It is observed that the birds prefer to construct nests in a corner. A pair of birds construct their nest together, and the male and female birds help to hatch and raise their chicks. Even if the nest is harvested three times, the female bird will construct a new nest with the male bird also helping (Jandam, 2017). During the mating season, the birds' salivary gland is larger than normal and before the nest is constructed the birds perch on the wooden plank and spit out their saliva while shaking their head. When the saliva dries, it will harden and stick to the plank. This preliminary stage of nesting is known by the local name kanom bueang (a Thai crispy pancake). Then, the birds will continue to build their nest during the night with their saliva flowing out in threads, which are overlapped and woven together to thicken the wall of the nest. This step of nesting is locally known as tang kiew (literally, eyebrows style). The first nest is completed in around 4-5 weeks. If the nest is harvested or destroyed before laying, the birds will build a new one together to replace it, which is called a "re-nest" (Pongchu, 1985; Lim, 1999; Jandam, 2017). However, if the nest is harvested or destroyed after eggs are laid, the birds will not build a substitute.

Generally, the female bird will lay two oval, white eggs with rough shells in the nest and the parents will take turns to hatch their eggs. When one of the birds is brooding, the other will go in search of food. The eggs are constantly brooded and take from 3 to 4 weeks to hatch. The newborn chicks are bald with pink skin and cannot open their eyes. To feed, the chicks open their mouths and raise their heads and the parents then regurgitate insects into their mouths. The baby birds are raised by their parents for 5 to 6 weeks. They initially develop 


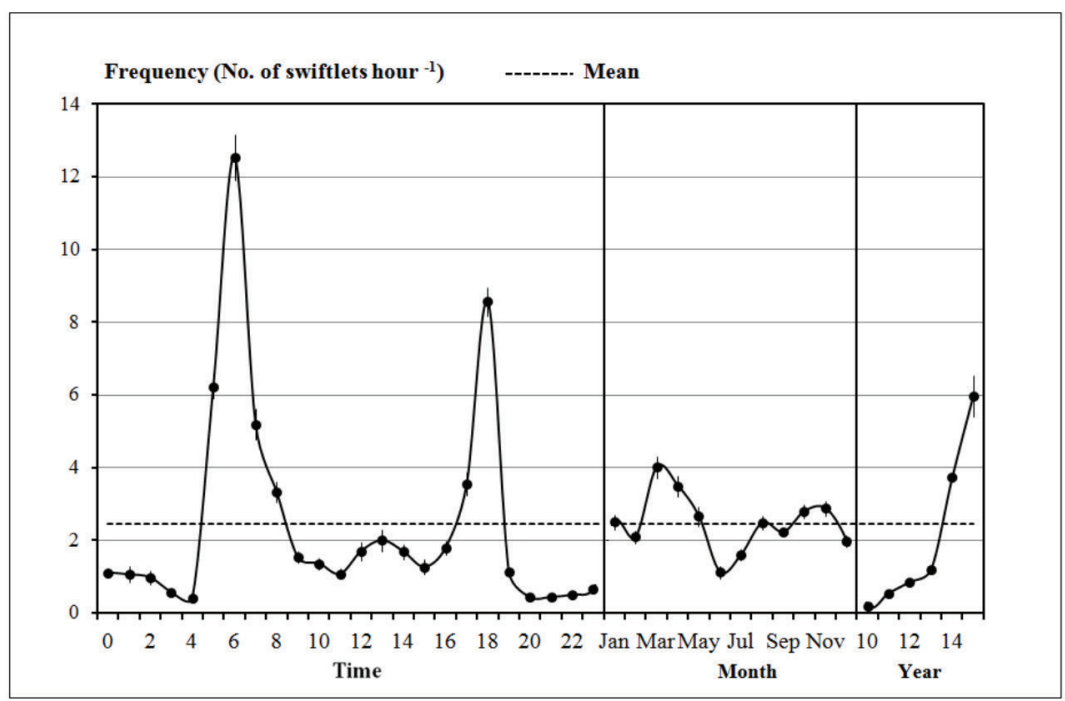

Figure 2: Swiftlets flying behavior inside or outside the master house (mean $\pm \mathrm{SE}$ birds per hour) observed from April 2010 until April 2016

body hair, and later feathers, enabling them to fly like other swiftlets.

\section{Bird's Nest Harvesting}

After the master house has been in operation for 2 years, the bird's nests can be harvested. However, the production was low at the start. Harvesting is carried out from $1 \mathrm{pm}$ to $3 \mathrm{pm}$, and only complete nests are harvested, which is accomplished with a polished stainless-steel trowel. The harvesters select only nests with no eggs or chicks. Since the initial production in the early years was low, the bird's nests were harvested every 3 to 4 months but later, when there were more bird's nests, the frequency increased to every 2 months. The harvested nests are sorted into three categories: cradle-shaped, triangular-shaped and scrap. The average weight of the three types of nest is $7.50 \pm 0.22 \mathrm{~g}$. The cradle-shaped nests, which are half-cup shaped, have an average weight of $7.77 \pm 0.48 \mathrm{~g}$, an average length of $8.17 \pm 0.19 \mathrm{~cm}$, an average width of $3.36 \pm 0.09 \mathrm{~cm}$ and an average depth of $1.68 \pm 0.12 \mathrm{~cm}$. The triangular-shaped nests, which have a curved base, have an average weight of $7.39 \pm 0.25 \mathrm{~g}$, an average length of $7.93 \pm 0.07 \mathrm{~cm}$, an average width of $4.16 \pm$ $0.05 \mathrm{~cm}$ and an average depth of $3.76 \pm 0.13 \mathrm{~cm}$.
The scrap nests, which do not fall into either shape category, have different weights and sizes. The nests in the master house are mostly white in colour speckled with birds' feathers and those nests which have been used to rear chicks also contain egg shell fragments.

\section{Temperature, Humidity and Lighting in the Master House}

The temperature in the house is quite important in relation to the physiological and metabolic processes of the birds. Changes in the air temperature in the master house are dependent on the design of the house, the use of the humidifier, the temperature outside the house during each season, and the intensity of the light and wind. These changes usually occur slowly and do not cause any problem for the birds. The data relating to the daily air temperature in the master house revealed that in November, December and January, the average air temperature was slightly lower than in other months at $27.48 \pm$ $0.03^{\circ} \mathrm{C}, 26.84 \pm 0.03^{\circ} \mathrm{C}$ and $26.85 \pm 0.03^{\circ} \mathrm{C}$, respectively, while in April, May and June, the average air temperature was slightly higher than in other months at $29.56 \pm 0.03^{\circ} \mathrm{C}, 29.79 \pm$ $0.03^{\circ} \mathrm{C}$ and $29.37 \pm 0.03^{\circ} \mathrm{C}$, respectively (Figure 3). However, the study found that although there 
was only a slight difference in the average air temperature each month throughout the year, the temperature inside the house was similar to the natural air temperature of $27-30^{\circ} \mathrm{C}$ in which the birds are used to (Ibrahim et al., 2009). It was also found that throughout the year, the average air temperature at night was lower than during the day. After sunset, the air temperature gradually decreased to the lowest level in the early morning before sunrise and at $6 \mathrm{am}$ and $7 \mathrm{am}$, the average air temperature was $26.61 \pm 0.03^{\circ} \mathrm{C}$ and $26.34 \pm 0.03^{\circ} \mathrm{C}$, respectively. After sunrise, the air temperature in the house gradually rose with the highest air temperature occurring in the afternoon. Thus, before sunset, at $5 \mathrm{pm}$ and $6 \mathrm{pm}$, the average air temperature was $29.83 \pm 0.05$ ${ }^{\circ} \mathrm{C}$ and $29.85 \pm 0.05{ }^{\circ} \mathrm{C}$, respectively (Figure $3)$. The change in the air temperature inside the house depended on the temperature outside the house, which was related to the intensity of the light striking the house.

Relative humidity is important for the growth and development of hatchlings inside the eggs, and chicks may not hatch or emerge abnormal if the humidity is too low. Changes in humidity in the master house is controlled by a humidifier, which operates at various times throughout the day, particularly in the afternoon when the air temperature is high. The relative humidity is usually high when the humidifier is operating but natural changes in the humidity also occur due to the air temperature and humidity outside of the house, the season and the wind. However, those changes usually occur slowly and do not affect the birds. Relative humidity data from the master house showed that during the day in May, June and July, the average relative humidity was $80.41 \pm 0.11 \%$, $79.37 \pm 0.14 \%$, and $80.49 \pm 0.11 \%$ respectively, while in November, December and January, the relative humidity was higher than in other months at $84.39 \pm 0.05 \%, 86.65 \pm 0.09 \%$, and $85.44 \pm 0.08 \%$, respectively (Figure 4). The humidity changed particularly due to the influence of rain, especially in December, when it rains for almost the whole month. However, the relative humidity of about $80-90 \%$ inside the master house is similar to the natural conditions in which the birds are used to living (Ibrahim et al., 2009). The relative humidity in the house gradually increases at night, especially after midnight, as the air temperature gradually decreases. The highest humidity was in the morning at 9.am, which averaged 85.22 $\pm 0.11 \%$. As the air temperature gradually increased, the relative humidity decreased, and

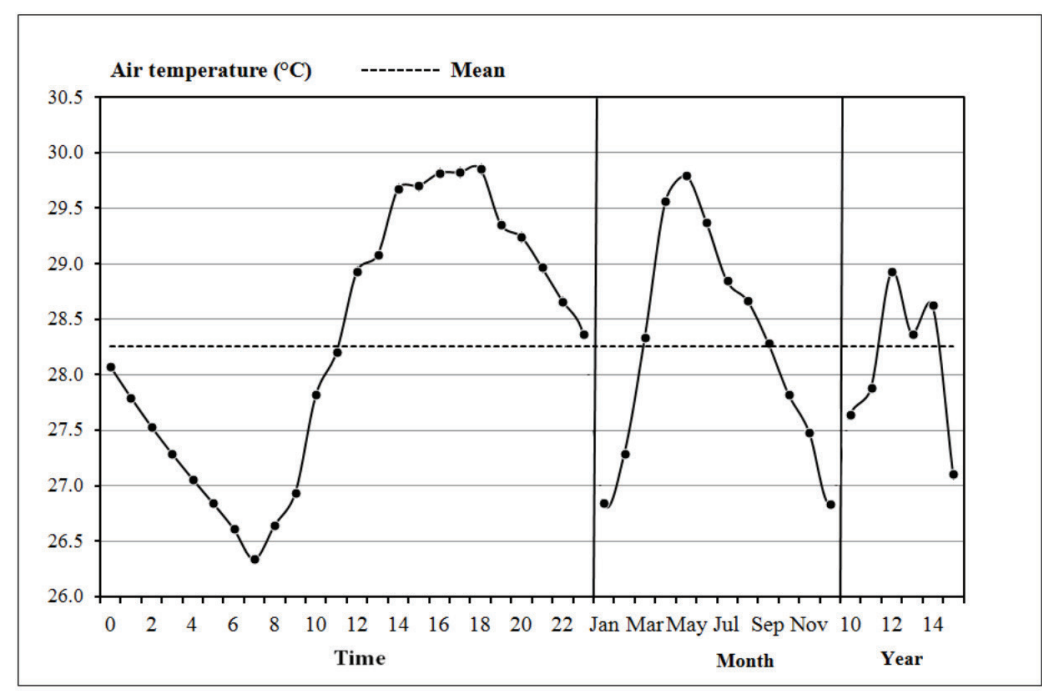

Figure 3: Change of air temperature (mean $\left.\pm \mathrm{SE}^{\circ} \mathrm{C}\right)$ inside the master house observed from April 2010 until April 2016 
at $6 \mathrm{pm}$, the average was $81.20 \pm 0.16 \%$ (Figure 4). However, in the afternoon, when the air temperature was quite high, and the humidifier was operated continuously, to maintain relative humidity in the house.

Overall, comparing the air temperature to the relative humidity in the master house during the day, it was found that the relative humidity was inversely related to the inside air temperature. During the summer, in April, May and June, as the air temperature rose, relative humidity was lower than in other months. During the monsoon season, in November, December and January, the air temperature in the house decreased, while the relative humidity was higher than in other months (Figures 3 and 4). However, the average relative humidity of $82.56 \pm 0.03 \%$ was still within the range in which these birds naturally live (Ibrahim et al., 2009).

Light is also important in regulating the birds' nesting behavior and, in particular, their tendency to construct their nests in hidden locations in order to avoid predators. In their natural habitat, the birds construct their nest in a dark area in a cave, and the birds can recognize the suitability of their habitat using their sensory organs (Pongchu, 1985; Ratree, 2003; Ponak,
2007; Ibrahim et al., 2009; Shirish \& Sankaran, 2010). The master house was designed, so that the light shone in through the entrance hole, the PVC pipe ventilators and also small slots in the brick wall. The average light intensity during the day in the master house was 11.6 - 11.8 lux. In November and December, the light intensity was slightly lower than in other months due to the monsoon season and the day was shorter than the night, with the average day and night light intensity at $11.42 \pm 0.04$ lux and $11.07 \pm$ 0.05 lux, respectively. However, there was little difference in the average light intensity between day and night throughout the year (Figure 5).

In conclusion, the data gathered throughout the experiment relating to the air temperature, humidity and light in the master house showed that the average air temperature in the house was $28.27 \pm 0.01{ }^{\circ} \mathrm{C}$, the average relative humidity was $82.56 \pm 0.03 \%$, and the average light intensity was $11.67 \pm 0.01$ lux. These results are similar to the natural conditions in which the birds generally live (Pongchu, 1985; Ibrahim et al., 2009; Shirish \& Sankaran, 2010). The results of this study are consistent with that of Rahman et al. (2018), who noted that edible birds' nest production was significantly higher in swiftlet houses with suitable environmental factors, such

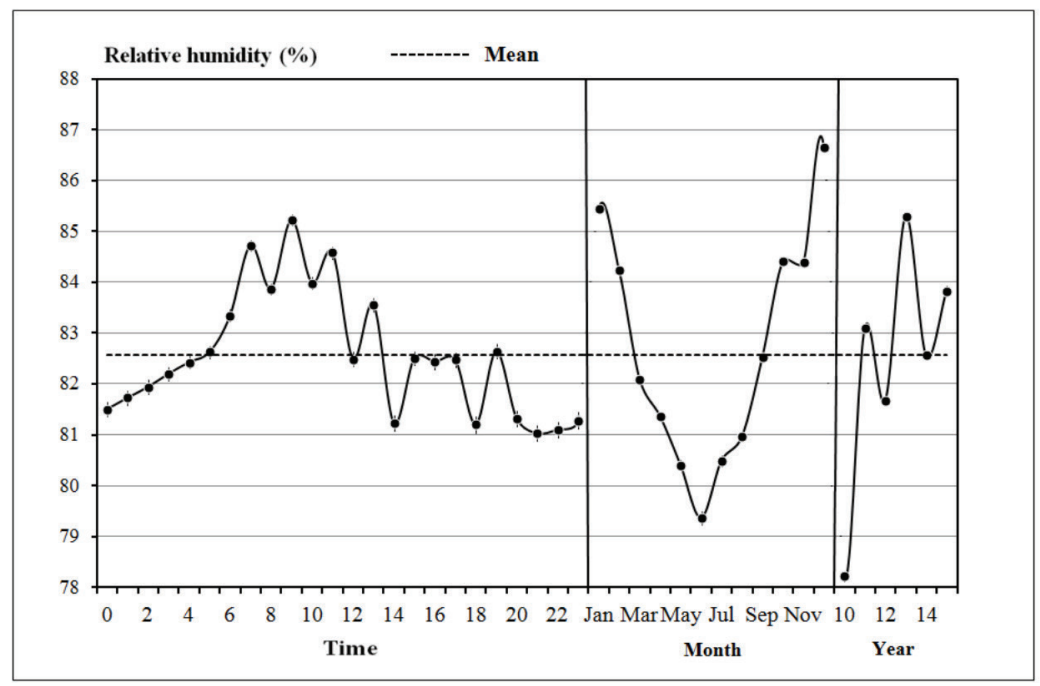

Figure 4: Change in relative humidity (mean \pm SE \%) in the master house observed from April 2010 until April 2016 


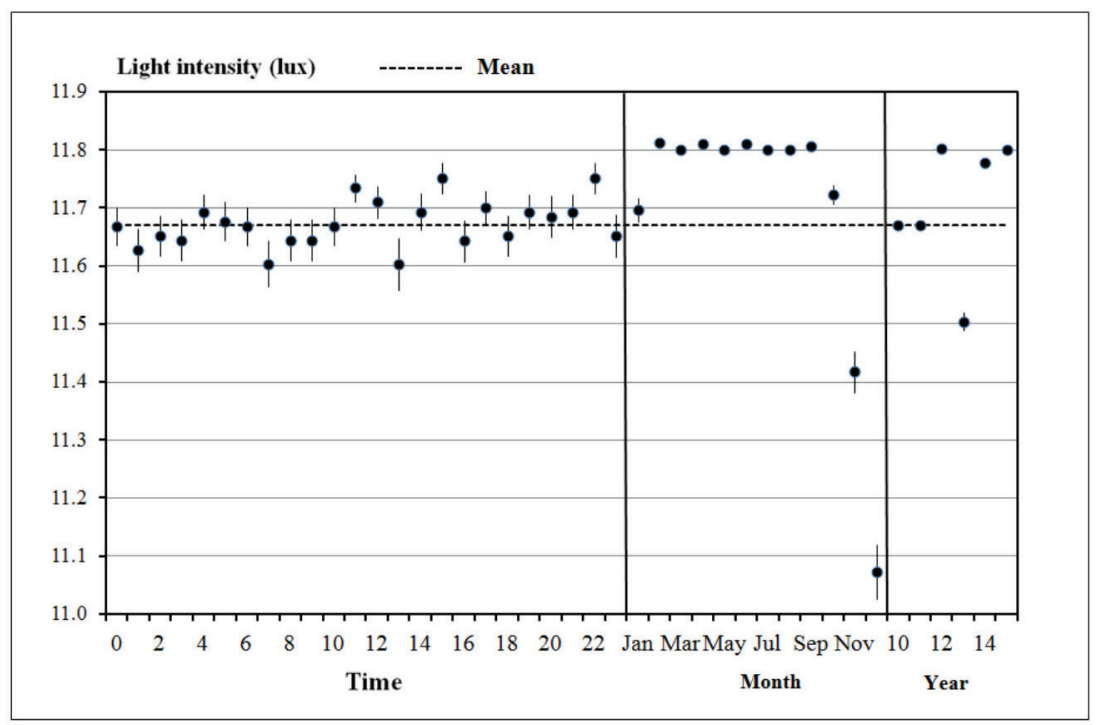

Figure 5: Changes in light intensity (mean $\pm \mathrm{SE}$ lux) inside the master house observed from April 2010 until April 2016

as air and surface temperature of around $30.1^{\circ} \mathrm{C}$, and relative humidity $83.7 \%$.

\section{Growth in The Bird's Nest Population}

The population of bird's nests was established by counting the number of nests in the nesting area of 60 square meters. Table 1 presents the data gathered from the beginning of the study in 2010 until 2016. It was found that 7 months after the construction of the master house there was only one nest and when the house was 1-year old, there were 6 nests. At 16 months, the house had 20 nests and at 26 months it contained 36 nests. After 38 months there were 84 nests, increasing to 129 nests after 51 months and 193 nests after 66 months. Therefore, based on the first nest being completed after 7 months and the number of nests after 66 months, the growth rate in the bird's nest population was:

$(\ln (193)-\ln (1)) /(66-7) \times 100=8.9$

or a population growth of $8.9 \%$ per month.

Figure 6 shows the growth profile of the birds' nest population which is revealed to be a curved line, where $y$ is the number of nests/area of 60 square meters and $x$ is the age of the house. The best trend line was derived in the form of a quadratic equation, where $y=0.0287 x^{2}+1.2787$ $x-11.7190\left(\mathrm{R}^{2}=0.9958, \mathrm{P}<0.001\right)$. It can therefore be seen that the population growth of the bird's nests will continue to increase because there are no limiting factors either inside or outside the house to impact the growth profile.

\section{Costs and Returns}

The returns from the investment in the master house can be calculated by deducting the expenses in construction and maintenance from the income from the production of birds' nests. The most important variables are the cost of production, the number of nests produced and the current price. There are fixed and operating costs and the return on investment is equal to the total income minus all the expenses.

Fixed costs include the value of the land, and expenses incurred preparing the land and constructing the house. These costs were estimated from the useful life of the house based on the principle of property valuation in accordance with the revenue code relating to asset valuation, where the cost of wages and/ or depreciation charged against the property does not exceed $5 \%$ of the annual costs. The depreciation was estimated based on the 
Table 1: The relationship between number of swiftlets' nests in the nesting area of 60 square meters and age of house

\begin{tabular}{ccc}
\hline Observation & Age of House (Months) & $\begin{array}{c}\text { Number of Swiftlets' Nests } \\
\text { (Maximum Number) }\end{array}$ \\
\hline 1 & 5 & 0 \\
2 & 7 & 1 \\
3 & 11 & 2 \\
4 & 12 & 6 \\
5 & 13 & 9 \\
6 & 14 & 12 \\
7 & 16 & 20 \\
8 & 20 & 22 \\
9 & 22 & 25 \\
10 & 26 & 36 \\
11 & 28 & 47 \\
12 & 29 & 51 \\
13 & 30 & 56 \\
14 & 34 & 60 \\
15 & 38 & 84 \\
16 & 45 & 106 \\
17 & 51 & 129 \\
18 & 56 & 154 \\
19 & 66 & 193 \\
\hline
\end{tabular}

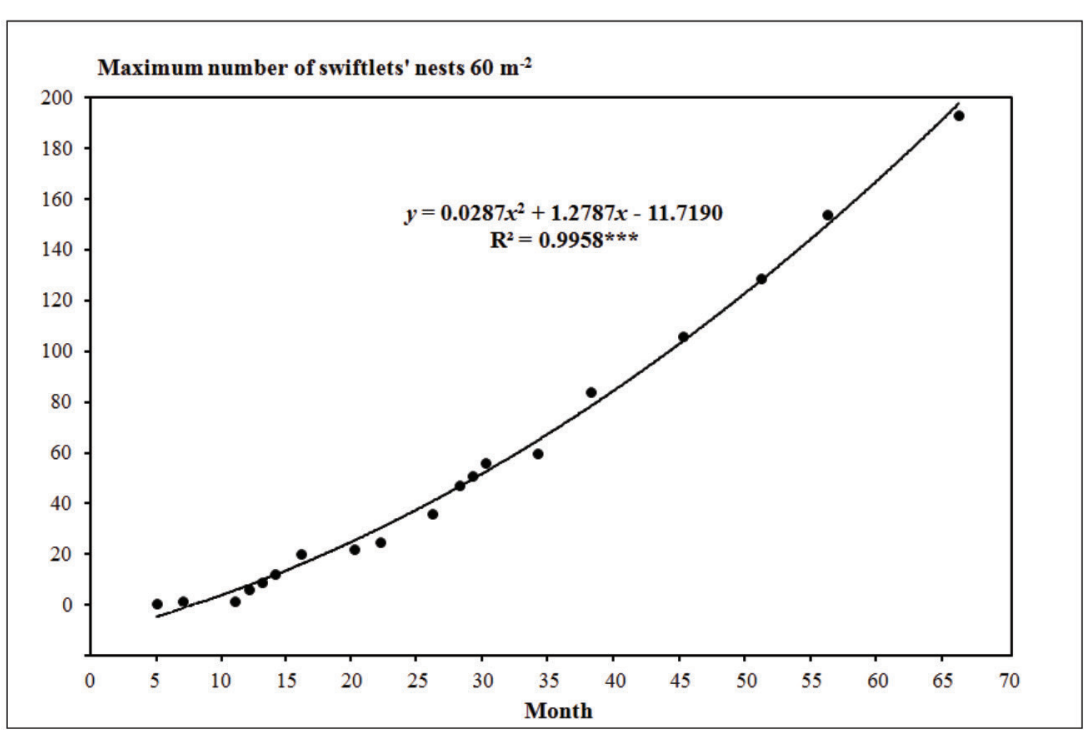

Figure 6: Growth curve of nest population in the master house over 66 months $(* * *$ significant at $\mathrm{P}<0.001)$ 
straight-line method, with an equal rate of depreciation every year over the useful life of the asset. The operational costs consisted of operating and maintaining the master house, including electricity, water, wages, fuel and transport (Table 2).

The income from the master house was based on the value of the nests produced. Since the nests were classified into three grades and each grade has a different price, the income was calculated using the average price per kilogram applied to the weight of bird's nest harvested each year and the average bird nest weight of 7.50 grams.

The payback period was calculated from the initial investment cost divided by the average net profit per year. The return and other economic indicators were calculated for 10 years, and the results showed that there was little production in the early years and the income after deducting the depreciation and operating expenses was very low. However, after about 4 years, the productivity and the income increased and thus the earnings after deducting the costs also increased. Thus, if the average price of birds' nest is USD596 or USD893 per kilogram, the payback period will be 5.7 and 3.3 years, respectively. However, if the average bird's nest price is USD298 per kilogram, the payback period will be more than 10 years (Table 3 ).

\section{Conclusion}

The construction of a low-cost ediblenest swiftlet house represents an economic opportunity. This study aimed to investigate how the design of the master house affected the edible-nest swiftlets, especially with regard to their habitat, livelihood, breeding, nesting and egg-laying. Data were collected from April 2010 to April 2016 and the temperature, humidity and lighting in the master house, the harvesting of the nest production, the growth of the bird's nest population and the cost of and returns from the master house were also investigated. The knowledge gained from this study will be beneficial to the development of low-cost edible-nest swiftlet master houses which can be constructed by farmers who wish to invest

Table 2: Fixed and operating costs and other expenses (USD) per year

\begin{tabular}{l|c|c|c}
\hline \multicolumn{1}{c|}{ Specification } & $\begin{array}{c}\text { Material Costs and } \\
\text { Wages }\end{array}$ & $\begin{array}{c}\text { Depreciation } \\
\text { (Cost Per Year) }\end{array}$ & \% \\
\hline 1. Fixed costs & 12,004 & 695 & 68.4 \\
1.1 Swiftlet house building & 10,982 & $549^{*}$ & 54.0 \\
(1) Piling and painting of steel frame & 1,495 & 75 & 7.4 \\
(2) Roof and roof structure & 3,189 & 159 & 15.7 \\
(3) Wall & 1,959 & 98 & 9.6 \\
(4) Insulation, doors and vents & 1,590 & 80 & 7.8 \\
(5) Nesting board & 2,749 & 137 & 13.5 \\
1.2 Tools \& Accessories & 1,021 & $146^{* *}$ & 14.4 \\
(1) Humidifier & 158 & 23 & 2.2 \\
(2) Sound system and speakers & 447 & 64 & 6.3 \\
(3) CCTV system & 417 & 60 & 5.9 \\
2. Operating costs & & 322 & 31.6 \\
(1) Electricity & & 197 & 19.3 \\
(2) Water supply & & 18 & 1.8 \\
(3) Wages & & 107 & 10.5 \\
\hline Total cost per year (1+2) & & 1,017 & 100 \\
\hline
\end{tabular}


Table 3: Comparison of return on investment from nest production with various nest prices for 10 years

\begin{tabular}{|c|c|c|c|c|c|}
\hline \multirow[t]{2}{*}{ Year } & \multirow{2}{*}{$\begin{array}{c}\text { Population } \\
\text { (no. of nests) }\end{array}$} & \multirow{2}{*}{ Nest kg per year } & \multicolumn{3}{|c|}{ Net profit per year (USD) } \\
\hline & & & 893 & 596 & 298 \\
\hline 1 & 8 & 0.17 & $861-$ & 913- & $965-$ \\
\hline 2 & 36 & 0.80 & $303-$ & $541-$ & 779- \\
\hline 3 & 72 & 1.61 & 421 & $58-$ & $538-$ \\
\hline 4 & 116 & 2.61 & 1,311 & 535 & 241- \\
\hline 5 & 168 & 3.79 & 2,367 & 1,239 & 111 \\
\hline 6 & 229 & 5.16 & 3,589 & 2,054 & 519 \\
\hline 7 & 298 & 6.71 & 4,977 & 2,979 & 981 \\
\hline 8 & 376 & 8.45 & 6,532 & 4,016 & 1,500 \\
\hline 9 & 461 & 10.38 & 8,253 & 5,163 & 2,073 \\
\hline 10 & 555 & 12.49 & 10,139 & 6,421 & 2,702 \\
\hline \multicolumn{3}{|c|}{ Average net profit per year (USD) } & 3,642 & 2,089 & 536 \\
\hline \multicolumn{3}{|c|}{ Initial investment (USD) } & 12,004 & 12,004 & 12,004 \\
\hline \multicolumn{3}{|c|}{ Payback period (years) } & 3.3 & 5.7 & $>10$ \\
\hline
\end{tabular}

in their own business. The master house was a single-story building. It was constructed with emphasis on saving costs by using low-cost materials. The house included an entrance hole, planks for nesting, a speaker, adequate ventilation, a water trough and a humidifier with a total fixed cost of USD12,004. The swiftlets living in the master house were of the species, Aerodramus fuciphaga. The birds use their curved claws to perch on the planks in the house by grasping the perpendicular edge of the plank. After 6 months, the birds build nests on the planks. The swiftlets have good eyesight and fly fast and spend the day hours catching flying insects as food. They fly out of the house in the morning and return at dusk. While flying inside the darkened house they used echolocation to navigate and to find their nests. The edible-nest swiftlet is able to reproduce throughout the year but its eggs are mostly laid in March, April and May. Before laying eggs, pairs of birds construct a half-cup or cradle shaped nest attached to a nesting plank from their gelatinous saliva. The nest takes around 4-5 weeks to construct. The female swiftlet from the pair lays two oval eggs. The eggs hatch within 3-4 weeks and the young birds are raised by their parents for 5-6 weeks. Initially they are bald but develop body hair and later feathers, enabling them to fly like other swiftlets. The air temperature, relative humidity and lighting in the master house had average values of $28.27 \pm 0.01{ }^{\circ} \mathrm{C}, 82.56$ $\pm 0.03 \%$, and $11.67 \pm 0.01$ lux, respectively. The specific growth rate of the bird's nest population was $8.9 \%$ per month. The return on investment was calculated based on the costs of building and operating the master house and the revenues from product sales. If the average price of the nest per kilogram is USD 893 the payback period would be 3.3 years, or at a price of USD 596, it would be 5.7 years. However, if the average price of nests per kilogram is USD 298 , the payback period would be more than 10 years.

\section{Acknowledgements}

We are very grateful to the research fund of the Faculty of Science and Technology Prince of Songkla University, Thailand, for their research grant. 


\section{References}

Altmann, J. (1973). Observational study of behavior: Sampling method. Illinois, IL: University of Chicago.

Biddle, F., \& Belyavin, G. (1968). The haemagglutination inhibitor in edible bird nest: Its biological and physical properties. Journal of General Microbiology, 31, 3144.

Brigham, E. F., \& Ehrhardt, M. C. (2004). Financial management theory and practice (11th ed.). New York, NY: South-Western College Publishers.

Brigham, E. F., \& Houston, J. F. (2001). Fundamentals of financial management (9th ed.). Orlando, FL: Harcourt Brace College Publishers.

Chantler, P. (1995). Swifts: A guide to the swifts and tree swifts of the world (2nd ed.). New Haven, CT: Yale University Press.

Chantler, P. (1999). Family Apodidae (swifts). In J. D. Hoyo, A. Elliott, and J. Sargatal (Eds.), Handbook of the birds of the world, Vol. 5: Barn Owls to Hummingbirds. (pp. 388-457). Barcelona, Spain: Lynx Edicions.

David, G., Roslan, A., Mamat, M. A., Abdullah, M. T., \& Hamza, A. A. (2016). A brief survey on birds from Pulau Perhentian Besar, Terengganu. Journal of Sustainability Science and Management, Special Issue Number I, 11-18.

Goh, D. L. M., Chua, K. Y., Chew, F. T., Liang, R. C., Seow, T. K., Ou, K. L., Yi, F. C., \& Lee, B. W. (2001). Immunochemical characterization of edible bird's nestallergens. Journal Allergy and Clinical Immunology, 107(6), 1082-1088.

Guo, C. T., Takahashi, T., Bukawa, W., Takahashi, N., Yagi, H., Kato, K., Hidari, K. I. P. J., Miyamoto, D., Suzuki, T., \& Suzuki, Y. (2006). Edible bird's nest extractInhibits influenza virus infection. Antiviral Research, 70(3), 140-146.
Hamza, A., David, G., Mcafee, A., \& Abdullah, M. T. (2018). Annotated checklist of Avifauna in Pulau Bidong, Malaysia. Journal of Sustainability Science andManagement, 13(1), 105-118.

Howe, C., Lee, L. T., \& Rose, H. M. (1960). Influenza virus sialidase. Nature, 188, 251252.

Howe, C., Lee, L. T., \& Rose, H. M. (1961). Collocalia mucoid: A substrate formyxovirus neuraminidase. Arch. Biochem. Biophys., 95(3), 512-520.

Ibrahim, S. H., Teo, W. C., \& Baharun, A. (2009). A study on suitable habitat for SwiftletFarming. UNIMAS E-Journal of Civil Engineering, 1(1), 1-7.

Jandam, K. (2017). Birds' nests, business and ethnicity in Southeast Asia.Bangkok, Thailand: The Thailand Research Fund (TRF).

Kang, N., Hails, C. J., \& Sigurdsson, J. B. (1991). Nest construction and egg-laying in Edible-nest Swiftlets Aerodramus spp. and implication for harvesting. Ibis, 133, 170177.

Kang, N., \& Lee, P. G. (1991). The Edible-nest Swiftlets Aerodramus spp. Nat. Malaysiana, 16, 44-51.

Kong, Y. C., Keung, W. M., Yip, T. T., Ko, K. M., Tsao, S. W., \& Ng, M. H. (1987). Evidence that epidermal growth factor is present in swiftlet's (Collocalia) nest.Comp. Biochem. Physiol. B., 87(2), 221-226.

Kong, Y. C., Tsao, S. W., Song, M. E., Ng, M. H., \& Lin, Z. (1989). Potentiation of mitogenic response by extracts of the swiftlet's (Apus) nest collected from Huai-Ji China. Acta Zoologica Sinica, 35(4), 429-435.

Krebs, C. J. (1972). Ecology: The experimental analysis of distribution and abundance. London, England: Harper \& Row.

Langham, N. (1980). Breeding biology of the Edible-nest Swiftlet (Aerodramus fuciphagus). Ibis, 122(4), 447-461. 
Lee, T. H., \& Kamini, N. (1987). Edible bird's nest: A potential product breakthrough. Paper presented at The 7th International traditional \& complementary medicine conference and exhibition (INTRACOMM) and 2nd International conference on biotechnology for wellness industry (ICBWI'09), July 23-26, 2009. Putra world trade centre (PWTC), Kuala lumpur, Malaysia.

Lekagul, B., \& Round, P. D. (1991). A guide to the birds of Thailand. Bangkok, Thailand: Saha Karn Bhaet.

Lim, C. K. (1999). Sustainable harvesting and conservation of the edible nest swiftlets (Aerodramus spp.) of Sarawak. PhD Thesis. University of Kent at Canterbury, United Kingdom.

Marcone, M. F. (2005). Characterization of the edible birds' nests the "Caviar of the East". Food Research International, 38(10), 11251134.

Matsukawa, N., Matsumoto, M., Bukawa, W., Chiji, H., Nakayama, K., Hara, H., \& Tsukahara, T. (2011). Improvement of bone strength and dermal thickness due to dietary edible bird's nest extract in ovariectomized rats. Biosci. Biotechnol. Biochem., 75(3), 590-592.

Nakagawa, H., Hama, Y., Sumi, T., Li, S., Maskos, K., Kalayanamitra, K., Mizumoto, S., Sugahara, K., \& Li, Y. (2007). Occurrence of a nonsulfated chondroitin proteoglycan in the dried saliva of Collocalia swiftest (edible bird's-nest). Glycobiology, 17(2), 157-164.

Nguyen, Q. P. (1994). Breeding and mouth in the Edible-nest Swiftlet Collocalia fuciphaga germani in Vietnam. Alauda, 62, 107-115.

Ponak, P. (2007). Some ecological aspects of Germain's swiftlet (Collocalia germani Oustalet) in Kho Chang National Park, Changwat Trat. [Master's thesis]. Kasetsart University, Thailand.
Pongchu, N. (1985). Biology of Edible-nest swiftlet (Collocalia fuciphaga (Thunberg, 1821)). [Master's thesis]. Kasetsart University, Thailand.

Rahman, M. A., Ghazali, P. L., \& Lian, C. J. (2018). Environmental parameters in successful edible bird nest swiftlet houses in Terengganu. Journal of Sustainability Science and Management, 13(1), 127-131.

Ratree, P. (2003). Habitat type, nesting and fledging development of Black-nest swiftlet (Collocalia maxima Hume, 1878) around Ko Chang National Park. [Master's thesis]. Kasetsart University, Thailand.

Robson, C. (2008). A field guide to the birds of Thailand and South-East Asia. Bangkok, Thailand: Asia Books.

Sankaran, R. (2001). The status and conservation of the Edible-nest Swiftlet (Collocalia fuciphaga) in the Andaman and Nicobar Islands. Biological Conservation, 97(3), 283-294.

Shirish, S. M., \& Sankaran, R. (2010). Foraging habit and habitat use by edible-nest and glossy swiftlets in the Andaman Island, India. The Wilson Journal of Ornithology, 122(2), 259-272.

Steel, R. G. D., \& Torrie, J. H. (1980). Principles and procedures of statistics: A biometrical approach (2nd ed.). International Student Edition. New York, NY: McGraw-Hill.

Viruhpintu, S. (2002). Breeding ecology of the white-nest swiftlet (Aerodramus fuciphagus (Thunberg, 1821)) in man-made and natural habitat. [Ph.D. Dissertation]. Chulalongkorn University, Thailand.

Viruhpintu, S., Thirakhupt, K., Pradatsundarasar, A., \& Poonswad, P. (2002). Nest-site characteristics of the edible-nest swiftlet Aerodramus fuciphagus (Thunberg, 1812) at $\mathrm{Si}-\mathrm{Ha}$ Islands, Phattalung Province, Thailand. Natural History, 2(2), 31-35. 
Yagi, H., Yasukawa, N., Yu, S. Y., Guo, C. T., Takahashi, N., Takahashi, T., Bukawa, W., Suzuki, T., Khoo, K. H., Suzuki, Y., \& Kato, K. (2008). The expression of sialylated high-antennary N-glycans in edible bird's nest. Carbohydrate Research, 343(8), 1373-1377. 